\title{
Study of mineral changes in patients with upper gastrointestinal cancer
}

\author{
Deepak P Birwatkar
}

Scientific Officer-D, Hematopathology, Hematopathology Laboratory. Tata Hospital, Annex Building, 5th floor, Parel, Mumbai, Maharashtra, INDIA.

Email: drsarane@gmail.com

\section{$\underline{\text { Abstract }}$}

\begin{abstract}
Background: Cancer has emerged as a major public health problem in developing countries, matching its effect in industrialized nations. It is a leading cause of death worldwide. In India, oesophagus and stomach cancers are reported to have higher incidence. Material and Methods: This comparative study carried out in patients suffering from oesophagus and stomach cancer and healthy subjects at KEM and Tata hospital, Mumbai. Sixty healthy and sixty cancer patients were enrolled in this study after confirming their eligibility based on inclusion criteria. The serum levels of calcium, phosphorus, zinc, copper and magnesium were measured. The data collected was statistically analysed and evaluated for correlation between parameters and type of cancer. Results: In both oesophagus and stomach cancer patients, serum calcium and serum phosphorus levels showed elevation in comparison to control group. Serum zinc and copper levels also remained elevated in oesophagus and stomach cancer patients but serum magnesium showed decrease levels in both cancer patients. Positive correlation studied between calcium/phosphorus, calcium/magnesium and copper/zinc ratios in both groups of cancer patients. Conclusion: Based on the data, association of selected minerals studied with oesophagus and stomach cancer patients can be observed. A well planned and extensive large sample study will be required to assess the therapeutic potential of minerals in decreasing the cancer risk.

Key Words: minerals, calcium, zinc, copper, phosphorus, magnesium, cancer, oesophagus, stomach.
\end{abstract}

\section{*Address for Correspondence:}

Dr. Deepak P Birwatkar, Scientific Officer - D, Hematopathology, Hematopathology Laboratory. Tata Hospital, Annex Building, 5th floor, Parel, Mumbai, Maharashtra, INDIA.

Email: drsarane@gmail.com

Received Date: 17/11/2019 Revised Date: 03/12/2019 Accepted Date: 11/01/2020

DOI: https://doi.org/10.26611/10021531

This work is licensed under a Creative Commons Attribution-NonCommercial 4.0 International License.

\begin{tabular}{|l|l|}
\hline \multicolumn{2}{|c|}{ Access this article online } \\
\hline Quick Response Code: & Website: \\
\hline & www.medpulse.in \\
& \\
\hline
\end{tabular}

\section{INTRODUCTION}

The origin of the word cancer is credited to the Greek physician Hippocrates who used the terms carcinos and carcinoma to describe non-ulcer forming and ulcer-forming tumors. In Greek, these words refer to a crab. The Roman physician, Celsus, later translated the Greek term into cancer, the Latin word for crab. Nowadays Cancer, among various diseases has become a big threat to human beings globally. This is the second most common disease after cardiovascular disorders for maximum deaths in the world. deaths in the world This is the second most common disease after cardiovascular disorders for maximum deaths in the world In spite of good advancements for diagnosis and treatment, cancer is still a big threat to our society (Kotnis et al, 2005). This is the second most common disease after cardiovascular disorders for maximum deaths in the world (Jemal et al, 2007). It accounts for about 23 and $7 \%$ deaths in USA and India, respectively. The world's population is expected to be 7.5 billion by 2020 and approximations predict that about 15.0 million new cancer cases will be diagnosed; with deaths of about 12.0 million cancer patients (Brayand et al, 2006). The prevalence of cancer in India is estimated to be around 2.5 million, with about 8, 00,000 new cases and 5, 50,000 deaths per annum (Nandakumar, 1990-96). According to 
1991 Indian census data, about 609000 cancer cases have been observed. This number had drastically increased to 806,000 by the end of the last century; with 96.4 and $88.2 \%$ age standardized rates for males and females; out of 100,000 cases analyzed (Rao et al, 1998). During last one decade, about $70 \%$ cancer cases have been diagnosed and treated with survival of a few patients (Dinshaw et al, 1999). It is believed that in near future the number of cancer patients will increase in the developing and under developed countries, which may rise up to $70 \%$; a serious issue for all of us. The magnitude of cancer problem in the Indian Sub-continent (sheer numbers) is increasing due to poor to moderate living standards (Wynder et al, 1974) and inadequate medical facilities. Most frequently observed cancers in Indian population are of lungs, breast, colon, rectum, stomach and liver (Nandakumar, 1990-96; Rao et al, 1998; Murthy et al, 2004). Nowadays, India is growing with a good progress rate and probably will become a developed country within a few decades resulting into its participation in the world development. Therefore, it is important to study the status of cancers in India so that advance measures may be taken to control this havoc in near future. In view of these facts, attempts have been made to study the status of cancers in India including its causes, preventive measures, effect on Indian economy and comparison with global scenarioThe prevalence of cancer in India is estimated to be around 2.5 million, with about 8,00,000 new cases and 5, 50,000 deaths per annum ${ }^{1}$. The magnitude of cancer problem in the Indian Sub-continent is increasing due to poor to moderate living standards 2 and inadequate medical facilities. Most frequently observed cancers in Indian population are of lungs, breast, colon, rectum, stomach and liver ${ }^{3,4}$. The causes of such high incidence rates of these cancers may be both internal (genetic, mutations, hormonal, poor immune conditions) and external or environmental factors (food habits, industrialization, over growth of population, social etc.). Most of the cancers have some relationships with diet. Predominant among them are cancers of the oesophagus, stomach, colon and liver. Carcinomas of the oesophagus are closely related to smoking and to the consumption of alcohol. With the absence of either of the risk is reduced by three quarters, the risk is reduced only very little more by the absence of both, as the two factors interact synergically. Nutritional deficiencies have probably also played a part particularly in the women. High rate of incidence is seen in China and India. Cancers of oesophagus recorded for $10 \%$ of all cancers in males and 5\% in females. ${ }^{5}$ Gastric cancer is the fifth most common cancer among males and seventh most common cancer among females in India. $^{3}$ The aggressiveness of the disease and need for improvement in therapeutic options is discerned by the fact the gastric cancer is the second most common cause of cancer death globally. ${ }^{6}$ Trace elements are the micronutrients that are part of daily diets and are required in minute quantity. These elements are very important in many different biological processes, such as normal healing, metabolism of genetic materials for growth and differentiation, function of structural nutrients, even in programmed cell death and necrosis. This helps in protection against oxidative injuries. These also possess anti-inflammatory and anti-carcinogenesis effect. But some elements are also involved in causation of undesirable events in vivo, such as participation in carcinogenesis and sustenance of cancerous cells. Role of lead, copper; chromium and zinc have been implicated in this effect. The in vivo utilization of trace elements is complex and not completely understood. They have redundancy of function because the same element may incite both positive and negative events depending upon its concentration and interaction with other trace elements. ${ }^{7}$ There are numerous influencing factors which decide the concentration of trace elements in body fluids and tissues, like sex and age, the dietary intake, uptake in the gastrointestinal tract, storage, excretion and the presence or absence of disease state. Studies have been undertaken to identify the appropriate tissue for estimating the bioactivity of these elements. However, for some of these elements like zinc, copper and selenium etc, the serum concentration has been found to be is a reliable measure of their bioactivity in the body, ${ }^{8}$ Stomach cancer is the second-most common cancer among men and third-most among females in Asia and worldwide. The symptoms and sign of the stomach cancer are often reported late when the disease is already in advanced stages and 5-year survival is less than $30 \%$ in developed countries and around $20 \%$ in developing countries. ${ }^{9}$ In India, the number of new stomach cancer cases in 2001 was estimated to be approximately $35,675(n=23,785$ in men; 11,890 in women). ${ }^{10}$ These differences in incidence rates can be attributed to many factors but refer particularly to differences in dietary habits, and infection to Helicobacter pylori. Esophageal cancer (EC) is the eighth most common cancer worldwide with a case fatality rate of $90 \%$. It is one of the malignancies with highest geographic, ethnic, and gender variations. In India, in states such as Karnataka, Tamil Nadu, Kerala, and Assam, EC is the most common gastrointestinal (GI) malignancy. ${ }^{11}$ Due to the inconsistencies in the documentations on trace elements and some minerals in cancer of the Oesophagus and stomach, the present study was planned to compare the serum concentration of major minerals and trace elements in serum of patients afflicted with oesophagus and stomach cancer and also study 
gender wise effect in these study groups in comparison to healthy controls.

\section{MATERIALS AND METHODS}

The present study was carried out in department of biochemistry of Seth GS Medical College and KEM Hospital, Mumbai and Tata Memorial Hospital, Mumbai after obtaining the sanction of the hospital ethics committee. Patients suffering from cancer were considered after confirming on inclusion criteria, referred either from Tata or KEM Hospital. In this study, 30 patients each in 2 groups suffering from oesophagus and stomach cancer along with 60 normal healthy in control group were evaluated. The study was carried out on newly diagnosed cancer patients and grouped them as given below;

\begin{tabular}{cccc} 
& Group I & Group II & Group III \\
\hline Cancer of organ & Healthy & Oesophagus cancer & Stomach \\
& No cancer & cancer \\
Male & 29 & 18 & 16 \\
Female & 31 & 12 & 14 \\
\hline
\end{tabular}

All these patients along with normal healthy controls were evaluated first clinically and then laboratory investigations like serum calcium, serum phosphorus, serum zinc, serum copper and serum magnesium were carried out. Blood samples collected by venepuncture, were allowed to clot at room temperature and serum was separated within 2 hours of withdrawal of blood and divided into aliquots which were stored at $4^{\circ} \mathrm{C}$ until analysed. Spectronic 20 Spectrophotometer, Shimadzu's UV- Spectrophotometer, Remi's refrigerated centrifuge, ordinary centrifuge and vortex mixture were used for estimation. The data collected from the analysis of serum were statistically analysed and evaluated for association between parameters and type of cancer.

\begin{tabular}{ccc}
\hline Estimation & Method & Normal range \\
\hline Serum Calcium & Baginski Method & $9-11 \mathrm{mg} / \mathrm{dl}$ \\
Serum Phosphorus & Gomorri Method & $2.5-4.2 \mathrm{mg} / \mathrm{dl}$ \\
Serum Zinc & William Method & $77.5-98.7 \mu \mathrm{g} / \mathrm{dl}$ \\
Serum Copper & Eden Method & $62.2-135.5 \mu \mathrm{g} / \mathrm{dl}$ \\
Serum Magnesium & Khayam-Bashi Method & $1.6-2.5 \mathrm{mg} / \mathrm{dl}$ \\
\hline
\end{tabular}

\section{RESULTS}

The principle elements like calcium, phosphorus; magnesium and trace elements like zinc and copper were assessed in the serum samples. The variations observed in the groups have been summarized in the tables below;

Table 1: Variations in Serum level (mean \pm SD) and range of parameters studied in different groups

\begin{tabular}{cccc}
\hline Minerals $\backslash$ Group & Normal (60) & Oesophagus CA (30) & Stomach CA (30) \\
\hline Calcium & $9.82 \pm 0.60$ & $9.38 \pm 0.74^{* * *}$ & $9.97 \pm 0.62$ \\
Phosphorus & $3.45 \pm 0.58$ & $3.37 \pm 0.54$ & $3.55 \pm 0.52$ \\
Zinc & $85.09 \pm 5.99$ & $106.55 \pm 8.77^{* * *}$ & $85.48 \pm 6.06$ \\
Cooper & $94.65 \pm 16.55$ & $98.86 \pm 18.16^{*}$ & $99.65 \pm 25.09$ \\
Magnesium & $2.03 \pm 0.27$ & $1.59 \pm 0.35^{* * *}$ & $1.74 \pm 0.32^{* * *}$ \\
\hline
\end{tabular}

$*: p<0.05 ; * *: p<0.01 ; * * *: p<0.001 ;$ NS : Not significant VS corresponding mineral values in Normal group (name of the test applied.)
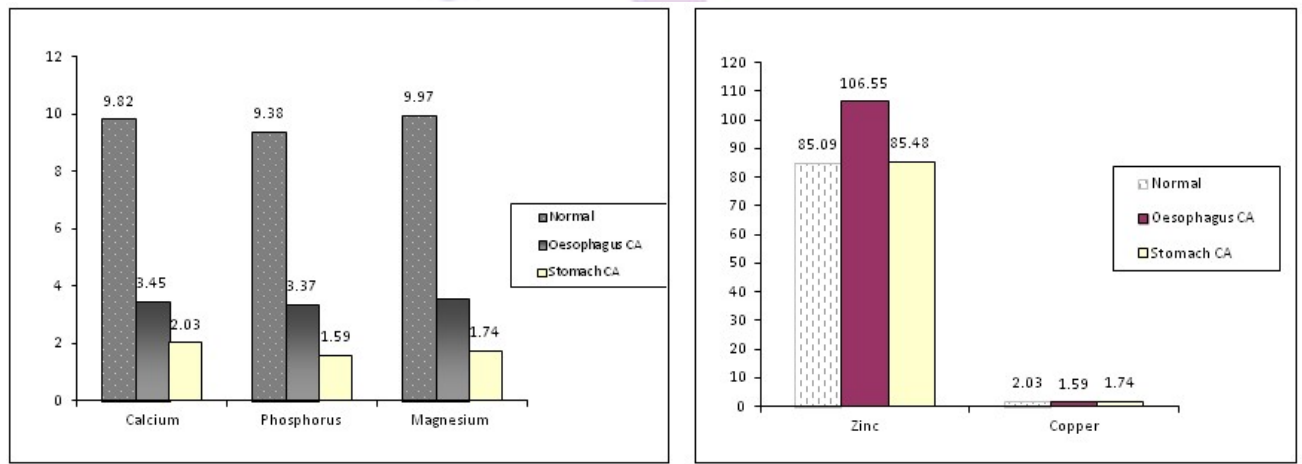

Graph 1: showing Variations in Serum level (mg/dl) in different groups; Graph 2: showing Variations in Serum level ( $\mu \mathrm{g} / \mathrm{dl})$ in different groups

Table 2: Variation in mean \pm SD and percent mean variation of different parameters studied in Normal (Gp I) and patients suffering from Oesophagus cancer (Gp II)

\begin{tabular}{cccc}
\hline Parameters & $\begin{array}{c}\text { Normal }(\mathrm{Gp} \mathrm{I}) \\
(\mathrm{n}=60)\end{array}$ & $\begin{array}{c}\text { Oesophagus Cancer } \\
(\mathrm{Gp} \mathrm{II})(\mathrm{n}=30)\end{array}$ & Percent mean variation \\
\hline Calcium $(\mathrm{mg} / \mathrm{dl})$ & $9.82 \pm 0.60$ & $9.38 \pm 0.74^{* * *}$ & 95.52 \\
Phosphorus $(\mathrm{mg} / \mathrm{dl})$ & $3.45 \pm 0.58$ & $3.37 \pm 0.54$ Ns & 97.68 \\
Zinc $(\mu \mathrm{g} / \mathrm{dl})$ & $85.09 \pm 5.99$ & $106.55 \pm 8.77^{* * *}$ & 125.22 \\
Copper $(\mu \mathrm{g} / \mathrm{dl})$ & $94.65 \pm 16.55$ & $98.86 \pm 18.16^{*}$ & 105.07 \\
Magnesium $(\mathrm{mg} / \mathrm{dl})$ & $2.03 \pm 0.27$ & $1.59 \pm 0.35^{* * *}$ & 78.33 \\
\hline
\end{tabular}


$*: p<0.05 ; * *: p<0.01 ; * * *: p<0.001 ;$ NS : Not significant

This table indicates statistically significant increase in percentage is observed for copper $(\mathrm{p}<0.05)$ and zinc $(\mathrm{p}<0.001)$. Decrease in levels was observed with calcium, phosphorus and magnesium.

Table 3: Variation in mean \pm SD and percent mean variation of different parameters studied in Normal (Gp I) and patients suffering from Stomach cancer (Gp III)

\begin{tabular}{cccc}
\hline Parameters & Normal $(\mathrm{Gp} \mathrm{I})(\mathrm{n}=60)$ & Stomach Cancer $(\mathrm{Gp}$ III) $(\mathrm{n}=30)$ & Percent mean variation \\
\hline Calcium $(\mathrm{mg} / \mathrm{dl})$ & $9.82 \pm 0.60$ & $9.87 \pm 0.62 \mathrm{NS}$ & 100.51 \\
Phosphorus $(\mathrm{mg} / \mathrm{dl})$ & $3.45 \pm 0.58$ & $3.55 \pm 0.52^{\mathrm{NS}}$ & 102.90 \\
Zinc $(\mu \mathrm{g} / \mathrm{dl})$ & $85.09 \pm 5.99$ & $85.48 \pm 6.06^{\mathrm{NS}}$ & 100.46 \\
Copper $(\mu \mathrm{g} / \mathrm{dl})$ & $94.65 \pm 16.55$ & $99.65 \pm 25.09^{\mathrm{NS}}$ & 105.91 \\
Magnesium $(\mathrm{mg} / \mathrm{dl})$ & $2.03 \pm 0.27$ & $1.74 \pm 0.32 * * *$ & 85.71 \\
\hline & $*: p<0.05 ; * *: p<0.01 ; * * *: p<0.001 ; \mathrm{NS}:$ Not significant
\end{tabular}

This table reveals marginal increase in mean \pm SD levels of all the parameters except magnesium in the patients suffering from stomach cancer (Group III) with respect to Normal group I subjects.

Table 4: Gender wise differentiation (mean \pm SD) and range in various parameters studied in different groups

\begin{tabular}{|c|c|c|c|c|c|c|}
\hline & Gender (n) & $\begin{array}{c}\text { Calcium } \\
(\mathrm{mg} / \mathrm{dl}) \\
(\mathrm{mean} \pm \mathrm{SD}) \\
\text { range }\end{array}$ & $\begin{array}{c}\text { Phosphorus } \\
\text { (mg/dl) } \\
\text { (mean } \pm \text { SD) } \\
\text { range }\end{array}$ & $\begin{array}{c}\text { Zinc } \\
(\mu \mathrm{g} / \mathrm{dl}) \\
(\text { mean } \pm \mathrm{SD}) \\
\text { range }\end{array}$ & $\begin{array}{c}\text { Cooper } \\
(\mu \mathrm{g} / \mathrm{dl}) \\
\text { (mean } \pm \mathrm{SD}) \\
\text { range }\end{array}$ & $\begin{array}{c}\text { Magnesium } \\
\text { (mg/dl) } \\
\text { (mean } \pm \text { SD) } \\
\text { range }\end{array}$ \\
\hline Normal & Male $(n=29)$ & $\begin{array}{l}9.85 \pm 0.51 \\
(9.0-11.0)\end{array}$ & $\begin{array}{c}3.47 \pm 0.65 \\
(2.5-5.5)\end{array}$ & $\begin{array}{l}84.90 \pm 6.91 \\
(77.2-98.7)\end{array}$ & $\begin{array}{l}98.13 \pm 16.64 \\
(68.2-131.5)\end{array}$ & $\begin{array}{c}2.00 \pm 0.29 \\
(1.8-2.5)\end{array}$ \\
\hline (Gp I) & Female $(n=31)$ & $\begin{array}{l}9.79 \pm 0.54 \\
(9.0-10.9)\end{array}$ & $\begin{array}{c}3.44 \pm 0.52 \\
(2.1-4.2)\end{array}$ & $\begin{array}{l}95.27 \pm 5.11 \\
(77.5-94.7)\end{array}$ & $\begin{array}{l}91.40 \pm 16.06 \\
(62.5-135.5)\end{array}$ & $\begin{array}{c}2.05 \pm 0.26 \\
(1.6-2.5)\end{array}$ \\
\hline Oesophagus cancer & Male $(n=18)$ & $\begin{array}{l}9.08 \pm 0.49 \\
(8.2-10.2)\end{array}$ & $\begin{array}{c}3.19 \pm 0.55 \\
(2.5-4.1)\end{array}$ & $\begin{array}{l}108.06 \pm 9.53 \\
(93.7-128.8)\end{array}$ & $\begin{array}{l}98.75 \pm 18.42 \\
(68.8-128.5)\end{array}$ & $\begin{array}{c}1.69 \pm 0.34 \\
(1.2-2.2)\end{array}$ \\
\hline (Gp II) & Female $(n=12)$ & $\begin{array}{l}9.84 \pm 0.82 \\
(8.9-11.2)\end{array}$ & $\begin{array}{c}3.63 \pm 0.43 \\
(2.9-4.2)\end{array}$ & $\begin{array}{l}104.28 \pm 7.28 \\
(96.6-120.2)\end{array}$ & $\begin{array}{l}99.03 \pm 18.59 \\
(70.2-120.2)\end{array}$ & $\begin{array}{c}1.48 \pm 0.35 \\
(1.1-2.3)\end{array}$ \\
\hline \multirow{2}{*}{$\begin{array}{l}\text { Stomach cancer } \\
\text { (Gp III) }\end{array}$} & Male $(n=16)$ & $\begin{array}{l}9.92 \pm 0.52 \\
(9.0-11.0)\end{array}$ & $\begin{array}{c}3.62 \pm 0.55 \\
(2.8-4.5)\end{array}$ & $\begin{array}{l}83.78 \pm 6.09 \\
(74.5-94.2)\end{array}$ & $\begin{array}{l}100.41 \pm 28.4 \\
(68.7-173.4)\end{array}$ & $\begin{array}{c}1.76 \pm 0.37 \\
(1.2-2.4)\end{array}$ \\
\hline & Female $(n=14)$ & $\begin{array}{l}9.82 \pm 0.65 \\
(9.0-10.8)\end{array}$ & $\begin{array}{c}3.47 \pm 0.49 \\
(2.8-4.2)\end{array}$ & $\begin{array}{l}87.45 \pm 5.60 \\
(79.8-94.7)\end{array}$ & $\begin{array}{l}98.78 \pm 21.60 \\
(75.5-131.4)\end{array}$ & $\begin{array}{c}1.70 \pm 0.27 \\
(1.3-2.2)\end{array}$ \\
\hline
\end{tabular}

Table 4 summarizes gender wise differentiation (mean $\pm \mathrm{SD}$ ) and range in various parameters studied in different groups.

Table 5: Variation in Mean \pm SD and percent mean variation of different parameters studied in males from Normal $(G p I)(n=29)$ and males from Oesophagus cancer patients (Gp II) ( $n=18)$

\begin{tabular}{cccc}
\hline & Normal & Oesophagus Cancer & Percent mean Variation \\
\hline Calcium $(\mathrm{mg} / \mathrm{dl})$ & $9.85 \pm 0.51$ & $9.08 \pm 0.49^{* * *}$ & 92.18 \\
Phosphorus $(\mathrm{mg} / \mathrm{dl})$ & $3.47 \pm 0.65$ & $3.19 \pm 0.55^{\mathrm{NS}}$ & 91.93 \\
Zinc $(\mu \mathrm{g} / \mathrm{dl})$ & $84.90 \pm 6.91$ & $108.06 \pm 9.53^{* * *}$ & 127.28 \\
Copper $(\mu \mathrm{g} / \mathrm{dl})$ & $98.13 \pm 16.64$ & $98.75 \pm 18.42^{\mathrm{NS}}$ & 100.63 \\
Magnesium $(\mathrm{mg} / \mathrm{dl})$ & $2.00 \pm 0.29$ & $1.69 \pm 0.34^{* * *}$ & 84.50 \\
\hline \multicolumn{2}{c}{$*: p<0.05 \cdot * * . p<0.01 \cdot * * * \cdot p<0001 \cdot \mathrm{NS} \cdot$ Not significant }
\end{tabular}

$*: p<0.05 ; * *: p<0.01 ; * * *: p<0.001 ;$ NS : Not significant

Table 5 data indicates statistically increase in serum zinc and decrease in mean levels of calcium, and magnesium.

Table 6: Variation in Mean \pm SD and percent mean variation of different parameters studied in males from Normal $(G p I))(n=29)$ and males

\begin{tabular}{cccc}
\multicolumn{4}{c}{ from stomach cancer patients $(\mathrm{Gp} \mathrm{III)}(\mathrm{n}=16)$} \\
\hline & Normal & Stomach cancer & Percent mean variation \\
\hline Calcium $(\mathrm{mg} / \mathrm{dl})$ & $9.85 \pm 0.51$ & $9.92 \pm 0.52^{\mathrm{NS}}$ & 100.71 \\
Phosphorus $(\mathrm{mg} / \mathrm{dl})$ & $3.47 \pm 0.65$ & $3.62 \pm 0.55^{\mathrm{NS}}$ & 104.32 \\
Zinc $(\mu \mathrm{g} / \mathrm{dl})$ & $84.90 \pm 6.91$ & $83.78 \pm 6.09^{\mathrm{NS}}$ & 98.68 \\
Copper $(\mu \mathrm{g} / \mathrm{dl})$ & $98.13 \pm 16.64$ & $100.41 \pm 28.48^{\mathrm{NS}}$ & 102.32 \\
Magnesium $(\mathrm{mg} / \mathrm{dl})$ & $2.00 \pm 0.29$ & $1.76 \pm 0.37^{*}$ & 88.00 \\
\hline \multicolumn{4}{c}{$: p<0.05 ; * *: p<0.01 ; * * *: p<0.001 ; \mathrm{NS}:$ Not significant }
\end{tabular}


In the above table, only serum magnesium level decreased statistically while the variations in other parameters are statistically insignificant.

Table 7: Variation in Mean \pm SD and percent mean variation of different parameters studied in females from Normal $(G p I)(n=31)$ and females from Oesophagus cancer patients (GpII) ( $n=12)$

\begin{tabular}{cccc}
\hline & Normal & Oesophagus cancer & Percent mean variation \\
\hline Calcium $(\mathrm{mg} / \mathrm{dl})$ & $9.85 \pm 0.51$ & $9.84 \pm 0.8249^{\mathrm{NS}}$ & 100.51 \\
Phosphorus $(\mathrm{mg} / \mathrm{dl})$ & $3.47 \pm 0.65$ & $3.63 \pm 0.43^{\mathrm{NS}}$ & 105.52 \\
Zinc $(\mu \mathrm{g} / \mathrm{dl})$ & $84.90 \pm 6.91$ & $104.28 \pm 7.28^{* * *}$ & 109.46 \\
Copper $(\mu \mathrm{g} / \mathrm{dl})$ & $98.13 \pm 16.64$ & $99.03 \pm 18.59^{\mathrm{NS}}$ & 108.35 \\
Magnesium $(\mathrm{mg} / \mathrm{dl})$ & $2.00 \pm 0.29$ & $1.48 \pm 0.35^{* * *}$ & 72.20 \\
\hline \multicolumn{4}{c}{$*: p<0.05 ; * *: p<0.01 ; * * *: p<0.001 ;$ NS $:$ Not significant }
\end{tabular}

The above table shows statistical significant variations in mean levels of zinc and magnesium. The zinc level shows significant increase $(\mathrm{p}<0.001)$ and magnesium shows significant decrease $(\mathrm{p}<0.001)$.

Table 8: Variation in Mean \pm SD and percent mean variation of different parameters studied in females from Normal $(G p I)(n=31)$ and females from stomach cancer patients (Gp III) ( $n=16)$

\begin{tabular}{cccc}
\hline Parameters & Normal & Stomach cancer & Percent mean variation \\
\hline Calcium $(\mathrm{mg} / \mathrm{dl})$ & $9.85 \pm 0.51$ & $9.82 \pm 0.65^{\mathrm{NS}}$ & 94.31 \\
Phosphorus $(\mathrm{mg} / \mathrm{dl})$ & $3.47 \pm 0.65$ & $3.47 \pm 0.49^{\mathrm{NS}}$ & 99.87 \\
Zinc $(\mu \mathrm{g} / \mathrm{dl})$ & $84.90 \pm 6.91$ & $87.45 \pm 5.60^{*}$ & 103.79 \\
Copper $(\mu \mathrm{g} / \mathrm{dl})$ & $98.13 \pm 16.64$ & $98.78 \pm 21.60^{\mathrm{NS}}$ & 100.07 \\
Magnesium $(\mathrm{mg} / \mathrm{dl})$ & $2.00 \pm 0.29$ & $1.70 \pm 0.27^{*}$ & 82.93 \\
\hline \multicolumn{4}{c}{$: p<0.05 ; * *: p<0.01 ; * * *: p<0.001 ; \mathrm{NS}:$ Not significant }
\end{tabular}

The above table indicates variations in mean levels of calcium, phosphorus, zinc and magnesium. The variation in zinc level is significant. Decrease in magnesium level is observed.

Table 9: Variations in Serum levels mean \pm SD and range of calcium/phosphorus, calcium/magnesium and copper/zinc ratios in different

\begin{tabular}{cccc}
\multicolumn{4}{c}{ groups } \\
\hline Parameters & $\begin{array}{c}\text { Calcium/ Phosphorus } \\
\text { Ratio/ Range }\end{array}$ & $\begin{array}{c}\text { Calcium/ Magnesium } \\
\text { Ratio /Range }\end{array}$ & Copper/Zinc Ratio/Range \\
\hline Normal (Gp I) & $2.92 \pm 0.50$ & $4.94 \pm 0.75$ & $1.11 \pm 1.67$ \\
( $\mathrm{n}=60$ ) & $(1.82-5.00)$ & $(3.68-6.56)$ & $(0.76-1.50)$ \\
Oesophagus cancer (Gp II) & $2.83 \pm 0.35$ & $5.15 \pm 1.32^{*}$ & $0.94 \pm 0.20$ \\
( $\mathrm{n}=30$ ) & $(2.22-3.52)$ & $(3.73-8.27)$ & $(0.59-1.26)$ \\
Stomach cancer (Gp III) & $2.84 \pm 0.43$ & $5.90 \pm 1.28^{*}$ & $1.16 \pm 0.26$ \\
( $\mathrm{n}=30)$ & $(2.22-3.93)$ & $(3.91-9.08)$ & $(0.84-1.94)$ \\
\hline
\end{tabular}

In case of Oesophagus cancer patients, marginal but insignificant decrease in calcium/ phosphorus ratio with respect to normal group is observed. Percentage increase in mean \pm SD level of calcium/ magnesium (104.25\%) and copper/zinc ratio is statistically significant. In case of Stomach cancer patients, increase in percent mean variation in calcium/ magnesium ratio is observed. With respect to normal group, insignificant decrease in calcium/ phosphorus and copper/zinc ratio is observed.

Table 10: Gender wise differentiation mean \pm SD and range of calcium/phosphorus, calcium/magnesium and copper/zinc ratios in different

\begin{tabular}{|c|c|c|c|c|}
\hline Parameters & Gender & $\begin{array}{c}\text { Calcium/ Phosphorus } \\
\text { Ratio } \\
\text { Range } \\
\end{array}$ & $\begin{array}{c}\text { Calcium/ Magnesium } \\
\text { Ratio } \\
\text { Range } \\
\end{array}$ & $\begin{array}{c}\text { Copper/ Zinc Ratio } \\
\text { Range }\end{array}$ \\
\hline \multirow[t]{2}{*}{ Normal (Gp I) } & Male $(n=29)$ & $\begin{array}{c}2.93 \pm 0.55 \\
(2.29-5.00)\end{array}$ & $\begin{array}{c}4.91 \pm 0.75 \\
(3.92-6.31)\end{array}$ & $\begin{array}{c}1.06 \pm 0.16 \\
(0.76-1.44)\end{array}$ \\
\hline & Female $(n=31)$ & $\begin{array}{c}2.90 \pm 0.46 \\
(1.82-3.81)\end{array}$ & $\begin{array}{c}4.97 \pm 0.76 \\
(3.68-6.56)\end{array}$ & $\begin{array}{c}1.16 \pm 0.16 \\
(0.86-1.50)\end{array}$ \\
\hline \multirow[t]{2}{*}{ Oesophagus cancer (Gp II) } & Male $(n=18)$ & $\begin{array}{c}2.69 \pm 0.30 \\
(2.22-3.52)\end{array}$ & $\begin{array}{c}6.42 \pm 1.35 \\
(3.87-8.27)\end{array}$ & $\begin{array}{c}0.96 \pm 0.18 \\
(0.56-1.24)\end{array}$ \\
\hline & Female $(n=12)$ & $\begin{array}{c}3.04 \pm 0.32 \\
(2.53-3.52)\end{array}$ & $\begin{array}{c}5.76 \pm 1.22 \\
(3.73-7.33)\end{array}$ & $\begin{array}{c}0.90 \pm 0.18 \\
(0.59-1.26)\end{array}$ \\
\hline Stomach cancer (Gp III) & Male $(n=16)$ & $\begin{array}{c}2.83 \pm 0.35 \\
(2.44-3.48)\end{array}$ & $\begin{array}{c}5.77 \pm 0.99 \\
(4.52-7.46)\end{array}$ & $\begin{array}{c}1.13 \pm 0.20 \\
(0.87-1.42)\end{array}$ \\
\hline
\end{tabular}


Female $(n=14)$

$2.84 \pm 0.54$
$(2.22-3.93$

Male patients in Oesophagus cancer group showed statistically significant increase in the calcium/magnesium ratio and decrease copper/zinc ratio whereas female patients in Oesophagus cancer group showed increase in calcium/magnesium ratio and decrease in the copper/zinc ratio. In case of male patients in stomach cancer group, data reveals only the statistically increase in calcium/magnesium ratio. Female patients in stomach cancer group showed percentage increase in the ratio of calcium/magnesium ratio which is statistically significant.

\section{DISCUSSION}

The biologic and pathologic role of minerals and trace elements are numerous, complex and their role apparently depends on the concentration and the balance of the positively and negatively implicated elements among other factors. Sometimes balance may lead to inconsistency. Due to multiplicity of function and the varying role depending on balance and concentration, the role of these elements is yet not fully elucidated. Zinc, most researched mineral, is an essential constituent of more than 100 enzymes and is essential for life. Through its function in nucleic acid polymerases, zinc plays a predominant role in nucleic acid metabolism, cell replication, tissue repair, and growth. ${ }^{12}$ Some epidemiological studies have suggested that higher levels of dietary zinc are associated with an increase in the incidence of cancer at several different sites, including the breast and stomach, and other studies have reported lower levels of zinc in the serum and tissue of patients with esophageal, bronchogenic, and other cancers, compared to corresponding levels in controls. ${ }^{13}$ In our study serum zinc levels in both gender showed increase in oesophagus and stomach cancer patients. The possibility that dietary exposure to copper, through the copper content of either foods or cookware, may play an etiologic role in gastric carcinogenesis is raised by the experiments of Endo et al 14, who found that the copper ion may be involved in conversion of creatine and creatinine to methylguanidine, a precursor of methylnitrosoguanidine. However, no epidemiological data on the relationship of gastric cancer and dietary copper have been reported. Magnesium deficiency may result in a variety of metabolic abnormalities and clinical consequences even cancer development. ${ }^{15}$ In our study reported increase in serum copper levels and decrease in serum magnesium levels in oesophagus and stomach cancer patients The association of serum trace elements and high cancer risk has been found in many studies. ${ }^{16,17,18,19}$ Sullivan F.et al. ${ }^{20}$ found that serum selenium and zinc levels were low while copper level were high in various human cancers in west Virginia. Mark et al. ${ }^{16}$ found that human squamous cell carcinoma esophagus patients had a significant low level of serum zinc as compared with age matched healthy controls $(\mathrm{P}<0.01)$. Umesh Kapil et al. ${ }^{21}$ observed that $53 \%$ of study people (Jharkand) had serum zinc deficiency and the deficiency was higher in females as compared to males. Limited data are available in India to show the association of cancer esophagus with serum level of trace elements ( $\mathrm{Zn}$, Copper, Selenium). The scientific community is convinced that both genetic and environmental factors play important role in oesophageal carcinogenesis. Although, inherited high susceptibility to oesophageal cancer accounts for part proportion of cases, exogenous exposures are also important for causing this disease. A number of studies have suggested that dietary factors are significant to the development of $\mathrm{EC}^{22,23,24}$ and there is evidence that different varieties of food and nutrients could play a role in protecting against this disease. ${ }^{25,26}$ A study conducted by Chen et $a l^{27}$ in china concluded that zinc and copper intake was inversely related to oesophageal cancer mortality and calcium intake level was positively related to oesophageal cancer mortality. Despite poor survival rates and a relatively high incidence in certain regions of the world, the impacts of mineral intake on the etiology of ESCC are unknown. Exposure to trace metals and tissue concentration of trace element is a modifiable risk factor. Hence, discovery of a credible and strong causal association between trace elements and cancer of the oesophagus and stomach may create a new frontier for the prevention and management of an established disease.

\section{CONCLUSION}

About the role of mineral intake in the development of oesophagus and stomach cancer, limited data is available. In this study, we tried to investigate a possible link of dietary calcium, phosphorus, copper, zinc and magnesium intake with oesophagus and stomach cancer risk. A well planned and extensive research will help in identifying therapeutic potential of use of minerals in these types of cancer patients.

\section{REFERENCES}

1. Nandakumar A. Consolidated report of the population based cancer registries. National Cancer Registry Programme. Indian Council of Medical Research, 199096; New Delhi, India.

2. Wynder EL, Covey LS, Mabuchi K Current smoking habits by selected background variables: Their effect on future disease trends. Am J Epidemiol, 1974;100:168177. 
3. Rao DN, Ganesh B Estimate of cancer incidence in India in 1991. Indian J Cancer, 1998; 35: 10-8.

4. Murthy NS, Mathew A Cancer epidemiology, prevention and control. Curr Sci 2004, 4-25.

5. Vincent T. DeVita, Theodore S. Lawrence, Steven A. Rosenberg DeVita, Hellman, and Rosenberg's Cancer: Principles and Practice of Oncology, J.P. Lippincort 1993

6. Alberts SR, Cervantes A, van de Velde CJ. Gastric cancer: Epidemiology, pathology and treatment. Ann Oncol. 2003;14:ii31-6.

7. Schwartz MK. Role of trace elements in cancer. Cancer Res 1975;35:3481-7

8. Hambidge M. Biomarkers of trace mineral intake and status. J Nutr 2003;133 Suppl 3:948S-55.

9. Mohandas KM, Jagannath P Epidemiology of digestive tract cancers in India. VI. Projected burden in the new millennium and the need for primary prevention. Indian $\mathrm{J}$ Gastroenterol. 2000 Apr-Jun; 19(2):74-8.

10. Corley DA, Buffler PA. Oesophageal and gastric cardia adenocarcinomas: Analysis of regional variation using the Cancer Incidence in Five Continents database. Int J Epidemiol 2001;30:1415-25

11. Chitra S, Ashok L, Anand L, Srinivasan V, Jayanthi V. Risk factors for esophageal cancer in Coimbatore, Southern India: A hospital-based casecontrol study. Indian J Gastroenterol 2004;23:19-21.

12. Prasad, A. S. Trace Elements and Iron in Human Metabolism. 1978. Plenum Publishing Corp., New York and London. $392 \mathrm{pp}$

13. National Research Council (US) Committee on Diet, Nutrition, and Cancer. Diet, Nutrition, and Cancer. Washington (DC): National Academies Press (US); 1982. 10 Minerals

14. Endo, H., M. Ishizawa, T. Endo, K. Takahashi, T. Utsunomiya, N. Kinoshita, K. Hidaka, and T. Baba. 1977. A possible process of conversion of food components to gastric carcinogens. Pp. 1591-1607

15. Weisinger R.J., Bellorín-Font E. Magnesium and phosphorus. Electrolyte quintet. The Lancet. 1998; 352: 391-396.
16. Mark, S.D., Qiao, L., Dawsey, S.M., et al. (2000).Prospective study of serum selenium levels and incident esophageal and gastric cancers. J. Natl.Cancer Inst. 92 (21), 1753-1763.

17. Kim, S.Y., Kim, J.W. et al. (2003). Changes in lipid peroxidation and antiozidant trace elements in serum of women with cervical intraepithelial Neoplasia and Invasive cancer. Nutrition and Cancer 47 (2). 126-130.

18. Milde, D. et al. (2001). Serum levels of selenium,maganese, copper and iron in colorectal cancer patients. Biological Trace Element Research 79 (2), 107114.

19. Tandon, M. et al. (2000). Role of micronutrients and trace elements in carcinoma of larynx. The Journal of the Association of Physicians of India 48, 995-8.

20. Sullivan, F., Alan, J., Blotcky, et al. (1979).Serum levels of selenium, calcium, copper, magnesium, magnise and zinc in various human diseases. J. Nutr. 109, 1432-1437.

21. Kapil, Umesh, Singh, Preeti and Pathak, Priyali (2003). Serum zinc levels amongst tribal population in a district of Jharkhand state (India) : A Pilot study. Eastern Journal of Medicine 8 (2),33-34.

22. De Stefani, E., Ronco, A. L. and Deneo-Pellegrini, H. Diet and risk of cancer of the upper aerodigestive tract - II. Nutrients. Oral Oncology,1999;35(1):22-26

23. Engel, L. S., Chow, W. H. and Vaughan, T. L. Population Attributable Risks of Esophageal and Gastric Cancers. Journal of the National Cancer Institute, 2003;95(18):1404-1413

24. Hung, H. C., Huang, M. C. and Lee, J. M. et al. Association between diet and esophageal cancer in Taiwan. Journal of Gastroenterology and Hepatology, 2004:19(6):632-637

25. Chen, H. L., Tucker, K. L. and Graubard, B. I. Nutrient Intakes and Adenocarcinoma of the Esophagus and Distal Stomach. Nutrition and Cancer,2002;42(1):33-40

26. Liaw, Y. P., Huang, Y. C. and Yeh, Y.C. (2003). Nutrient intakes in relation to cancer mortality in Taiwan. Nutrition Research, 2003;23(12):1597-1606

27. Chen F, Cole P, Mi Z, Xing L.Dietary trace elements and esophageal cancer mortality in Shanxi, China. Epidemiology 1992 Sep;3(5):402-6.
Source of Support: None Declared Conflict of Interest: None Declared 